\title{
Changing Character of Pool -Riffle Sequence: A Quantitative Representation of Long Profile of Ichamati, India
}

\author{
Madhab Mondal ${ }^{1}$, Dr.L. N. Stapati ${ }^{2}$ \\ Assistant Teacher, Bhowanipur S. J. Institution, Hasnabad North 24 Parganas, W. B ${ }^{1}$ \\ Professor, Department of Geography, University of Calucutta, Kolkata, W. B ${ }^{2}$
}

\begin{abstract}
The river Ichamati, which drains the eastern part of the district North 24 Pgs. W.B., India, has been analyzed regarding its long profile of the two years( 2004 and 2012) based on two windows. This paper has focused on the character of long profile such as, pool-riffle sequence and deviation index, which reveal the evolutionary tendency of long profile.

Bed deformation technique (bdt) has identified the number and position of the pool and riffle on the riverbed. The classification of pool and riffle has been done with the help of tolerance value $(T)$. The magnitude of $T$ values is different in two windows. According to tolerance value (T), the position and number of pool and riffle has been changed significantly in two windows in two years. The threshold value of T has also been differed from 2004 to 2012. All these indicate the gradual decay of the river Ichamati.
\end{abstract}

Keywords: windows, long profile, pool-riffle sequence, deviation index, evolutionary tendency, Bed deformation technique, tolerance value.

\section{INTRODUCTION}

River management is not only merely a technical task but and sedimentary dynamics of the basin ( Costigan et al., also inherently a socio-economic and cultural issue that 2014; Sinha and Parker, 1996; Leopold and Maddock reflect societal value (Higgs, 2003). In the last two 1953) and the slope of the stream along its axis, including decades, the management of rivers has become stream characteristics such as knickpoints, riffles, pools, multifunctional procedure built upon a holistic base such and Changes in vegetation, land use, surface geologic as scientific knowledge, engineering interventions, control materials (soils, sediments, and rocks), slopes, and of pollution, water resource management, fisheries, hydrology may be monitored to assess this vital sign transport, energy economy and protection of rivers (Lord et al., 2009), occur in response to both extrinsic and (Lehotsky and Grešková, 2007). Rivers are the arteries of intrinsic controlling variables ( Schumm and Lichty, 1965 the landscape and also a geomorphologic processes create ). The long profile is influenced by the distribution of dynamic and diverse habitats, both in stream and in pools and rifles (Harmer and Clifford 2007; Anderson et riparian and flood plain environments ( Dorava et al., al. 2005; Madej, 1999). Geomorphological research on 2001; Petts and Amoros, 1996 ), floodplain features are pools and riffles has shown that theses bed forms are determinants of the diversity of habitat any given river ( fundamental elements of meandering streams ( Krueger et Brierley, 2008 ). In modern sosirty there is a conflict al, 2007; Bhowmik and Demissie, 1982; keller and between the dynamics of channel and human resource Melhorn, 1978; Wolman, 1955 ). The development of development with the outcome that many rivers and alternating deeps (pools) and shallows (riffles) are riparian environments have been significantly modified characteristic of both straight and meandering channel and damaged (Brookes and Shields, 1996). In the last two with heterogeneous bed materials in the size range of 2decades, the river management of has developed as a $256 \mathrm{~mm}$ (Jackson and Beschta, 1984; Lisle, 1982) and multifunctional procedure built upon a holistic based that pools are zones of convergent flow and scour, while riffles unites the scientific knowledge, engineering interventions, are zones of divergent flow and deposition ( Beschta and control of pollution, water resource management, fisheries, Platts, 1986; Clifford, 1983), The pool-riffle bedform transport, energy economy and protection of rivers. sequence is a significant element in the dynamic (Guneralp and Marston, 2012; Lehotsky and Grešková adjustment between form and process in alluvial streams ( 2007).

Clifford and Richards, 1992 ).

Ichamati is an irregular sinuous distributary channel, Pools have been defined morphologically as topographic anthropologically delinked from the Padma- lows along a longitudinal stream profile ( O'Neil and Mathabhanga- Churni system in early 1970s, making it a Abrahams, 1984 ) and research have shown that they deranged, default and non-flowing water course ( Sarkar, generally have asymmetrical cross sectional shape ( 2004 ) and also a tidal creek that is classified as C type Frothingham et al, 2002; Knighton, 1981 ), develop within river ( Knighton, 1998 ). Longitudinal profiles of rivers are the broader context of stream behavior ( Knighton, 1998 ), representative of watershed evolution, geologic structure,

different forms and secondary circulation occur in riffles 
and pools (Richards, 1982 ) and Pools and riffles are interrelated with the meandering plan-form ( Richards, 1976a ), where pools typically occur at the outside of bends, and rimes are located in straight reaches between bends ( Yang, 1971 ). In pools, flow is 'convergent' at the surface and so floating debris collects in the shallow hollow at mid channel where the flow phenges. In riffles, surface 'divergent' flow occurs, with a sight surface super elevation where the mid channel current rises ( Ritter et al, 1995; Beschta and Plalts, 1986; Cliford, 1983; Richards, 1982; Bathurst et al, 1979; Hey,1975 ), pool spacing is between five and seven times the channel width (Keller and Melhorn, 1978; Leopold et al, 1964 ). Leopold and Langbein (1962) applied for the first time the concepts of physical entropy to study the behavior of streams. Their applications were based on the analogy between heat energy and temperature in a thermodynamic system and potential energy and elevation, respectively in a stream system. Two thermodynamics principles were applied; the first principle is that the most possible state of a system is the one of maximum entropy. The second is the principle of minimum entropy production rate ( Yilmaz 2006, p 325 ). In rivers "the principle of least work is one of several ways in which the condition of maximum probability may be satisfied. The river channel has the possibility of internal adjustment among hydraulic variables to meet the requirements for maximum probability and these adjustments tend also to achieve minimization of work" (Leopold and Langbein, 1962). The condition of minimum work and uniform distribution of work cannot simultaneously be achieved, and in many aspects of river morphology it is observed that the opposing tendencies lead to a compromise. Minimum work in the river system would result in a very concave profile ( Langbein and Leopold, 1964). Unequal distribution of stream bed materials creates undulating form of long profile, and so there are uneven distributions of internal energy per unit mass is reached as the velocity and depth trend toward uniformity in a river system (Yilmaz, 2006). A natural river can be thought of as an open system with inflows and out flows of energy and matter (Knighton, 1998; Leopold and Longbein, 1962). Such a view point emphasizes the important characteristics of stream behavior the external constraints or controls imposed on the system; the adjustment to the internal geometry of the system in response to these controls and the nature of that adjustment, especially as regards any tendency towards system equilibrium (Knighton, 1998).

This paper examines the present day longitudinal change and the impact of human interference along a $55 \mathrm{~km}$ reach of the Ichamati river. We have presented longitudinal profiles of two different years and compared them with each other and with the computed graded profile to analysis its utmost profile condition.

In order to attain this objective, we are taking the following steps: 1) to define the research area and the data basis 2) bed deformation and their geomorphological evaluation 4) to study the deviation of the present day profile to equilibrium profile (Mondal and satpati , 2012) and 6) conclusion.

\section{THE STUDY AREA}

The study area includes the Indian portion of the middle Ichamati river basin (Kalanchi Bridge to Basirhat Bridge) under the police stations of Gaighata, Swarupnagar, Baduria and Basirhat. All of these police stations are located at the eastern portion of the district of North 24 Parganas of the state of West Bengal, and cover an area of about 1884.96 sq. km. Geographically, the study area is situated between $22^{0} 10^{\prime} \mathrm{N}$ to $23^{0} 11^{\prime} \mathrm{N}$ and $88^{0} 37^{\prime} \mathrm{E}$ to $89^{\circ} \mathrm{E}$ (Fig.1) .

The district of North 24 Parganas of West Bengal is in the southern part of the Bengal Basin. The Basin is actually a peri-cratonic basin and comprises of Ganga- Bramaputra Delta in the southern part (Basu et al., 2003). River Ichamati is the main drainage system in the eastern part of the district. The Ichhamati, which receives the Jamuna at Charghat (North 24 Parganas), is another beheaded distributary at present. It takes off from the Mathabhanga at Majhdia, east of Krishnanagar, and flows southward in a sinuous course along Bangaon, Charghat and IndoBangladesh border (Rudra, 2014) Bangal Basin is one of the major sedimentary basins in Indian subcontinent. Ganga Brahmaputra and cratonic river systems, bringing the sediments from the Himalayas and the surrounding Indian shield area, have converted the area as one biggest modern delta system in India (Roy et al., 2010). Bengal delta is formed by a chain of fluvio- tectonic actions operating over the neo-miogeosyncline of the Bengal Basin. Stratigraphically, a section of the upper Cretaceous limestone and calcareous shale overlies the upper Mesozoic basalt flows and associated trap wash, granite wash rocks near Ghatal, debgram and jalangi, deposited under brackish, marshy, esturine lagoon or partially litoral environments (Sengupta, 1966). Geological investigations reveal that the sub-surface geology is completely blanketed by the quaternary sediments comparising a succession of silty clkay, sand of various grades and sand mixed with occasional gravels and thin intercalations of silty clay (Sikdar. et. al, 2009). In West Bengal the average depth of the water level in the target area of north 24 parganas very from $1.02 \mathrm{~m}$ to $6.36 \mathrm{~m}$ below ground level (bgl) for the mouth of January. In april, it is from $2.13 \mathrm{~m}$ to $7.85 \mathrm{~m} \mathrm{bgl}$ and in November from $0.62 \mathrm{~m}$ to $4.22 \mathrm{~m} \mathrm{bgl} \mathrm{(} \mathrm{Smith} \mathrm{et} \mathrm{al.,} \mathrm{2003).} \mathrm{Early} \mathrm{report} \mathrm{on} \mathrm{the}$ hydrology of the area suggests that there are shallow aquifer $(12-15 \mathrm{~m}$ below ground level $\mathrm{bgl})$ in the upper plain and is mostly under unconfined conditions except near its southern fringe where it occurs under semi-confined to confined conditions. There is generally a southeasterly gradient of the water surface sub parallel to the general slope of the area. All the aquifers are interconnected due to spatial variations in grain size (Basu et al. 2003, Chakraborty et al, 2009). It embraces the moribund delta in the north, matured delta in the middle, and active delta in the south and a depressed zone of brackish marshes between the active and the mature delta. Most of the soils derived from alluvial deposits are azonal with little or no profile development. Clay loam is the predominating type. Clays with or without muck soils occur in swamps and alluvial lakes. 




Fig.1.Location of studied streams.

These soils have been formed from deposits brought by tidal currents. The active delta still growing southwards is a system of innumerable tidal rivers, canals and creeks, saline soils, swamps and marshes. A part of this active delta contains forests. Known as Sunder bans, this part of the active delta region is under reserve forests. Even then the area of Sunder bans spread over 24 Parganas (north and south) is 0.42 million hectares (1629 sq. km.). The study area experiences tropical climate having alternate warm wet summers and cool dry winters. The lion share rain fall occurs in the study area due to the southwest monsoon. The mean maximum temperature in the monsoon season is $36.3^{\circ} \mathrm{C}$ and the mean minimum temperature is $23.48^{0} \mathrm{C}$.
The recent mean maximum temperature is higher $\left(36.3^{\circ} \mathrm{C}\right.$, $1998-2002)$ then the time period of $1881-1940\left(34.86^{\circ} \mathrm{C}\right)$.

The rainfall data does not show the same natural phenomenon. The average yearly maximum monsoon rainfall is $959.4 \mathrm{~m} . \mathrm{m}$. And the maximum monthly average rainfall is $231.8 \mathrm{~m} . \mathrm{m}$. Though the above report is a generalized form but there is a regional variation within the study area. In Basirhat region the average yearly rainfall is $1542.7 \mathrm{~m} . \mathrm{m}$. And average monthly rainfall during the monsoon period is $514.2 \mathrm{~m} . \mathrm{m}$.

In Tentulia P.S. the average yearly monsoonal rainfall is $959.4 \mathrm{~m} . \mathrm{m}$. and average monthly monsoon rainfall is $231.8 \mathrm{~m} . \mathrm{m}$. 


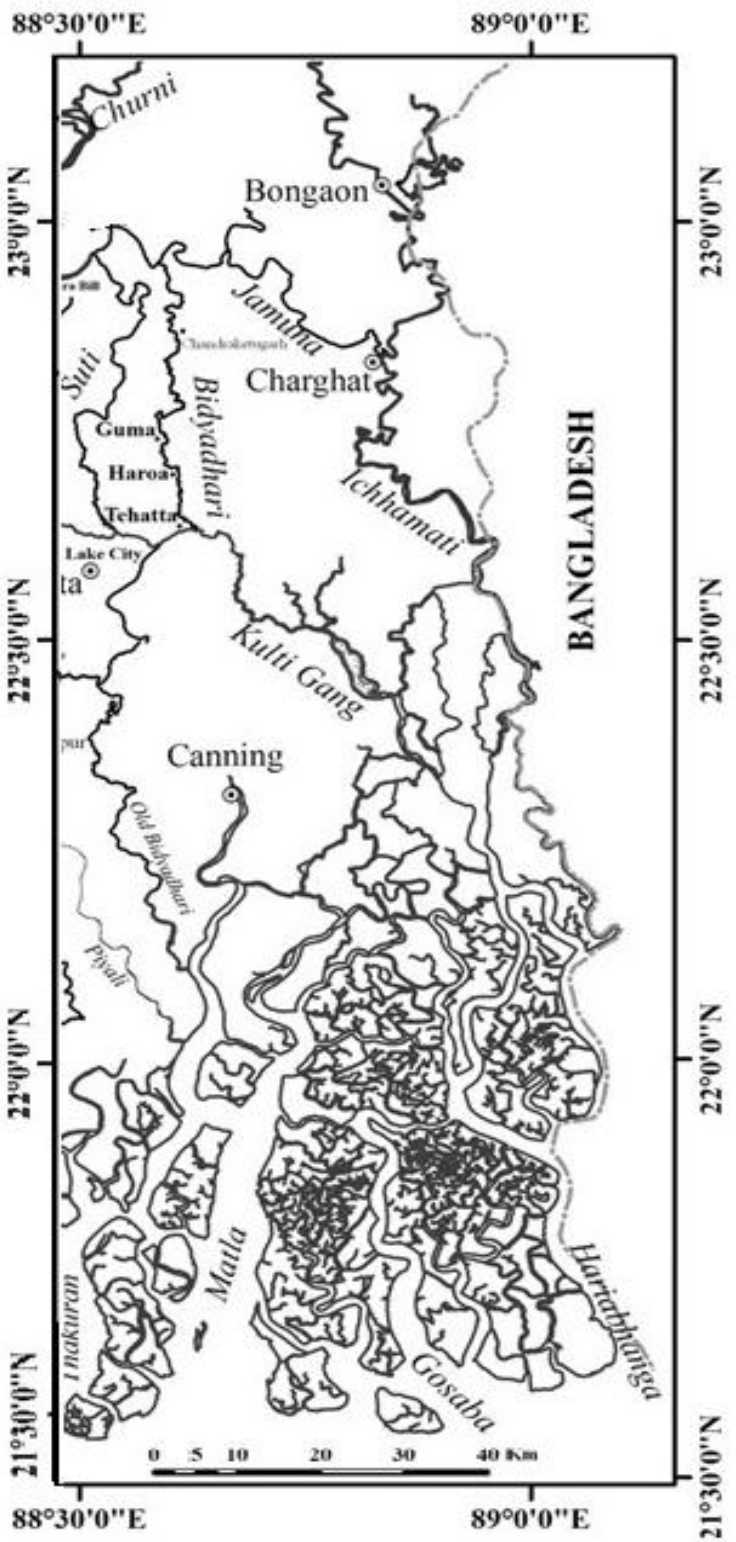

Fig.2 Location of Ichamati in drainage network of Bengal Basin

\section{METHOD}

\subsection{Data collection}

The primary data sets of two year, e.g., 2004 and 2012 were used here to identify trends within the long profile of the Lower Ichamati River. The hydrographic survey undertaken in 2004 and in 2012. The survey of crosssections undertaken intensively ( 7 times to width of the river) with the help of conventional string/ pole sounding, which was reach calibrated by modern echo-sounding measures taken at selected points. The survey, therefore, provides a high-resolution data set from which to study the long profile (Harmer, 2004). In the lower stretches or in the second window, we have surveyed the river through modern eco-sound method and after that the final adjustment (to create the long profile) has been calibrated based on local datum (14ft). Because here the river is so deeper and velocity is so high to conduct the conventional pole method. Then the river has been divided into two windows, so that all reaches were comparable in terms of channel length (Harmar and Clifford,2007), and width, based on homogeneity of the collected data. We have compared the geomorphic conditions of long profiles of each window based on their own parameters and finally compared with the unit profile.

\subsection{Identification of pool and riffle:}

Researchers have identified pools and riffles through a variety of methods e.g. regression method (Richards (1976a), the control-point method (Yang, 1971); the zerocrossing method (Dury, 1970); and power spectral analysis (Box and Jenkins, 1976; Bloomfield, 1976). When compared with the regression technique, the differencing technique proves more dependable in correctly identifying riffles and pools (O'Neill and Abrahams, 1984). Advantages of the technique lie in the fact that it avoids spatially consistent results, it involves basic mathematics and is therefore easy to employ, and it avoids the problem of identification of excessively long or short bed-forms (Foster, 1998). We have divided the long profile of river Ichamati, into two reaches in terms of channel depth. In this case, bed deformation technique (bdt), (O'Neill and Abrahams, 1984) has been used to identify pool and riffle. We used the surveyed bed elevations to calculate the bed elevation difference series from upstream to downstream for each reach: B1 - B2, B2 - B3, where Bx is equal to the bed elevation $(\mathrm{m})$ of the thalweg at each survey point $(\mathrm{x})$. We then calculated the standard deviation (SD) of the bed elevation difference series. This was used to calculate a tolerance value ( $\mathrm{T}$ ) to define the minimum absolute value needed to identify a pool or a riffle. We investigated several $\mathrm{T}$ values $(0.25 \mathrm{SD}, 0.5 \mathrm{SD}, 0.75 \mathrm{SD}, 1.0 \mathrm{SD}, 1.25 \mathrm{SD})$ for this study. Lastly, we calculated the bed elevation difference at each survey point or series of points from the last identified bed form and compared it to the $\mathrm{T}$ value to identify the locations of pools and riffles (i.e., the absolute minimum and maximum bed elevations in each reach)( Harmar and Clifford, 2007; Krueger and Frothingham, 2007; Frothingham and Brown, 2000; Foster, 1998 ). We have taken the $0.75 \mathrm{SD}$ as $\mathrm{T}$ value (for first window, $\mathrm{T}=0.99,2004$, and for second window, $\mathrm{T}=0.24,2004)$ and have taken the 0.1.5SD, $0.75 \mathrm{SD}$ as $\mathrm{T}$ value (for first window, $\mathrm{T}=0.96,2012$, and for second window, $\mathrm{T}=2.72$, 2012) to identify the pool and ripple.

\section{RESULTS AND DISCUSSION}

4.1. Identify the basis form of long profile

(a) Bed deformation and their geomorphological evaluation

We divided the river Ichamati into two reaches $\left(1^{\mathrm{St}}\right.$ window: 0-26 km and 2nd window: 26- $55 \mathrm{~km}$ ) based on homogeneity of width- depth and studied them separately. The mean depth of the 1 st window during the low tidal level (L.T.L.) is about $2.34 \mathrm{~m}$. but the second ones having $10 \mathrm{~m}$. In average. The other geomorphic and hydrological parameters are also taken into account (Table -4) those helped us to demarcate the boundary of the windows. We have taken two sets of $\mathrm{T}$ value for two windows to select the pools and riffles, e.g., for the first window $\mathrm{T}_{\mathrm{A} 2004}\{\mathrm{~T} 1$ 
$(0.25 \mathrm{SD})=0.33, \mathrm{~T} 2(0.5 \mathrm{SD})=0.66, \mathrm{~T} 3(0.75 \mathrm{Sd})=0.99, \mathrm{~T} 4 \quad(0.75 \mathrm{SD})=0.24, \mathrm{~T} 4 \quad(1 \mathrm{SD})=0.33, \mathrm{~T} 5 \quad(1.25 \mathrm{SD})=0.41\}$ and $(1 \mathrm{SD})=1.33, \mathrm{~T} 5(1.25 \mathrm{SD})=1.66\}$ and $\mathrm{T}_{\mathrm{A} 2012}\left\{\mathrm{~T} 1(0.5 \mathrm{SD})=\mathrm{T}_{\mathrm{B} 2012} \quad\{\mathrm{~T} 1 \quad(0.25 \mathrm{SD})=0.9, \mathrm{~T} 2 \quad(0.5 \mathrm{SD})=1.81, \mathrm{~T} 3\right.$ $0.32, \quad \mathrm{~T} 2 \quad(1.0 \mathrm{SD})=0.64, \quad \mathrm{~T} 3 \quad(1.55 \mathrm{Sd})=0.96, \quad \mathrm{~T} 4 \quad(0.75 \mathrm{Sd})=2.72, \quad \mathrm{~T} 4 \quad(1 \mathrm{SD})=3.63, \quad \mathrm{~T} 5 \quad(1.25 \mathrm{SD})=4.53\}$ $(2 \mathrm{SD})=1.28$, T5 $(1.5 \mathrm{SD})=1.6 \mathrm{\}}$ and for the 2nd window (Table-1).

, $\mathrm{T}_{\mathrm{B} 2004}\{\mathrm{~T} 1(0.25 \mathrm{SD})=0.08, \mathrm{~T} 2(0.5 \mathrm{SD})=0.16, \mathrm{~T} 3$

Table 1 Different T value of two windows in 2004 and 2012

\begin{tabular}{|c|c|c|c|c|c|c|c|c|c|c|c|}
\hline \multirow{2}{*}{ SD } & \multirow{2}{*}{$\mathbf{T}_{\mathrm{A}}$} & \multicolumn{4}{|c|}{$\begin{array}{l}\text { 1st Window-2004 } \\
(0-26 \mathrm{~km})\end{array}$} & \multirow[t]{2}{*}{ SD } & \multirow{2}{*}{$\mathrm{T}_{\mathrm{A}}$} & \multicolumn{4}{|c|}{$\begin{array}{c}\text { 1st Window-2012 } \\
(0-26 \mathrm{~km})\end{array}$} \\
\hline & & $\mathbf{P}$ & $\mathbf{R}$ & MP & MP & & & $\mathbf{P}$ & $\mathbf{R}$ & MP & MR \\
\hline 0.25 & 0.33 & 16 & 7 & 01 & 03 & 0.5 & 0.32 & 19 & 8 & - & - \\
\hline 0.5 & 0.66 & 13 & 14 & - & - & 1 & 0.64 & 15 & 10 & 2 & - \\
\hline 0.75 & 0.99 & 09 & 17 & - & - & 1.5 & 0.96 & 11 & 14 & 1 & 1 \\
\hline 1 & 1.33 & 08 & 18 & - & - & 2 & 1.28 & 3 & 24 & - & - \\
\hline \multirow[t]{2}{*}{1.25} & 1.66 & 04 & 23 & - & - & 2.5 & 1.6 & 1 & 25 & - & 1 \\
\hline & $T_{B}$ & \multicolumn{4}{|c|}{$\begin{array}{l}\text { 2nd Window-2004 } \\
\text { (26-55KM) }\end{array}$} & & $\mathrm{T}_{\mathrm{B}}$ & \multicolumn{4}{|c|}{$\begin{array}{c}\text { 2ND Window-2012 } \\
(26-55 \mathrm{~km})\end{array}$} \\
\hline 0.25 & 0.08 & 28 & 0.0 & - & - & 0.25 & 0.9 & 10 & 16 & 1 & 1 \\
\hline 0.5 & 0.16 & 20 & 7 & - & 01 & 0.5 & 1.81 & 3 & 24 & - & 1 \\
\hline 0.75 & 0.24 & 18 & 8 & - & 01 & 0.75 & 2.72 & 2 & 26 & - & - \\
\hline 1 & 0.33 & 16 & 09 & - & 03 & 1 & 3.63 & 2 & 26 & - & - \\
\hline 1.25 & 0.41 & 16 & 12 & - & - & 1.25 & 4.53 & 2 & 26 & - & - \\
\hline
\end{tabular}

Table 2 No. and corresponding area of pool and riffles in two windows in 2004 and 2012

\begin{tabular}{|c|c|c|c|c|c|c|c|c|}
\hline \multirow{3}{*}{ Year } & \multicolumn{4}{|c|}{ Pool } & \multicolumn{4}{|c|}{ Riffle } \\
\hline & \multicolumn{2}{|c|}{$1_{\text {window }}^{\text {st }}$} & \multicolumn{2}{|c|}{$2^{\text {nd }}$ window } & \multicolumn{2}{|c|}{$1^{\text {st }}$ winow } & \multicolumn{2}{|c|}{$2^{\text {nd }}$ window } \\
\hline & $\begin{array}{l}\text { Total } \\
\text { No. }\end{array}$ & $\begin{array}{l}\text { Area } \\
\text { sq. } m\end{array}$ & $\begin{array}{l}\text { Total } \\
\text { No. }\end{array}$ & $\begin{array}{l}\text { Area } \\
\text { sq. } m\end{array}$ & $\begin{array}{l}\text { Total } \\
\text { No }\end{array}$ & $\begin{array}{l}\text { Area } \\
\text { sq.m }\end{array}$ & $\begin{array}{l}\text { Total } \\
\text { No. }\end{array}$ & $\begin{array}{l}\text { Area } \\
\text { sq. m }\end{array}$ \\
\hline 2004 & 4 & 3325 & 5 & 620 & 9 & 1250 & 3 & 700 \\
\hline 2012 & 3 & 885 & 3 & 750 & 4 & 1030 & 11 & 2040 \\
\hline
\end{tabular}

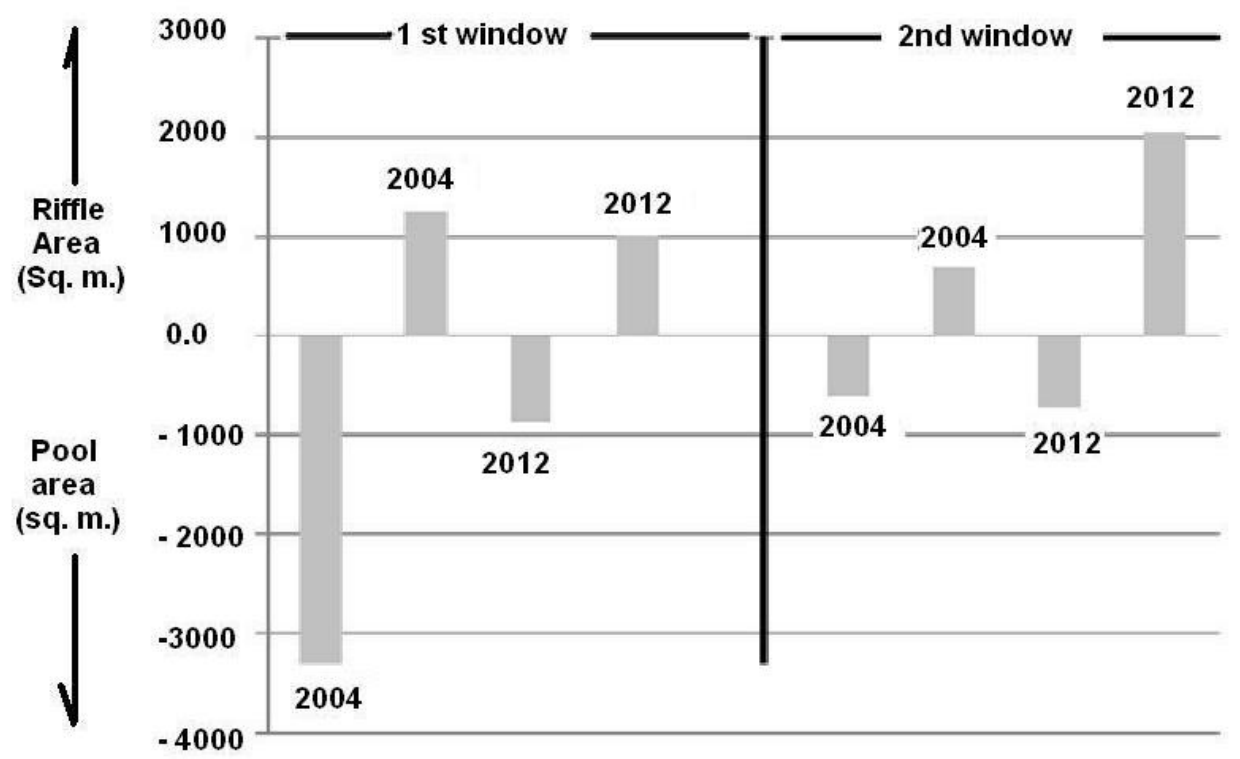

Fig .3 Changing area of pools and riffles in two different years (2004 and 2012) 
By increasing the $\mathrm{T}$ value, the number of bed forms identified decreases (Foster, 1998). A ' $\mathrm{T}$ ' greater than the optimum value overlooks many features, including some identified as riffles in the field, while a ' $\mathrm{T}$ ' less than optimum value identifies every small bed undulation places crests/bottoms. Therefore, a middle most position of $\mathrm{T}$ value has taken as the optimum value e.g., 0.75 SD (0.99) and a T value of 1.5 SD (0.96) have taken from the both set for first window. Alike, we have taken a $\mathrm{T}$ value $(0.75 \mathrm{SD})=0.24$ and a $\mathrm{T}$ value $(0.75 \mathrm{Sd})=2.72$, for the second window. The first window of long profile -2004 , exhibited seven pools and nine riffles whereas the second window exhibited four pools and two ripples. The pool area was about 3325 sq. m. in first window and 620 sq. m. in second window of the long profile -2004. On the other hand, pools occupied 1250 sq. $\mathrm{m}$. area in the first window and 700 sq. m. in the second window. We have identified five pools and four riffles in the first window ( $T=0.96$, 2012) and two pools and twelve riffles in the second window $(T=0.99)$ on the long profile 2012. In the first window, the riffle area, has reached to 1030 sq. m (2012) from 1250 sq. $m$ (2004) at a decreasing rate of $17.6 \%$ and the pool area also shows a decreasing rate of $73.38 \%$ that was from 3325 sq.m (2004) to 885 sq.m. in 2012 (Table-2) (Fig-2).

In the second window, the profile represents the opposite picture. The riffle area has increased at a rate of $191.42 \%$ (700 sq. m. in 2004 and 2040 sq. m. in 2012). Comparatively, the increasing rate of pool area is low $(20 \%)$.

(b) Pool- riffle sequences (P-R sequence)

In the first window, only a small portion of the long profile $2004(\mathrm{~T}=0.99)$ exhibited a regular orientation of pool-riffle sequence, e. g., between, $2 \mathrm{~km}$. - $12 \mathrm{~km}$. : Riffle - Pool - Riffle-Pool-Riffe (R-P-R-P-R), and between, 12 km. $-14 \mathrm{~km}$. : $\mathrm{P}-\mathrm{R}-\mathrm{P}$. However, these orientations seldom met the requirements of the existence for the bend or inflection zone. But the longitudinal profile -2012, ( $\mathrm{T}=$ 0.96) very rarely represents the orientation of pool- ripple sequence e.g., between, $7 \mathrm{~km}-11 \mathrm{~km} .: \mathrm{R}-\mathrm{P}-\mathrm{R}$ (FIG-3).
There were 13 no. of bed features $(P=4, R=9)$ in the first window, in the profile2004. But in 2012, these number have turned into $7(\mathrm{P}=3, \mathrm{R}=4)$ at a decreasing rate of $46.15 \%$. This picture has converted into opposite one in the second window, in 2012. The number of bed forms has increased at a $75 \%$, from $8(\mathrm{P}=5, \mathrm{R}=3)$ to $14(\mathrm{P}=3, \mathrm{R}=11)$. The bed forms of long profile in second window shows a rapid changing character. In second window, we have selected a $\mathrm{T}$ value $0.24(0.75 \mathrm{SD})$ for the long profile-2004 and a $\mathrm{T}$ value $2.72(0.75 \mathrm{SD})$ for the long profile- 2012 to identify pools and riffles. We have identified four pools and three riffles (without regular spacing) with the help of a $\mathrm{T}$ value 0.24 , in the profile of 2004 and the profile 2012 , represents two pools and twelve riffles $(\mathrm{T}=2.72)$. A reach, between $32 \mathrm{~km}$ to $45 \mathrm{~km}$ of profile 2004 , was without any feature. Subsequently, that very reach, exhibits seven riffles $(\mathrm{T}=2.72)$ in 2012 , due to rapid siltation. In this reach regular spacing of pool-riffle sequence only noticed at between $52 \mathrm{~km}$ to $55 \mathrm{~km}$ ( P-R-P-R, T-2.72) in the profile of 2012 (Fig-3). The numbers of bed forms have increased at a $75 \%$ from $8(\mathrm{P}=5, \mathrm{R}=3)$ to $14(\mathrm{P}=3, \mathrm{R}=11)$.

These discussions have revealed the followings:

The decreasing rate of pool area indicates the rapid siltation and incompetency of river transportation.

Slow growth rate of riffle does not match with rapid siltation because there were frequent 'de-siltation of river bed programme' in 2005-2007, for better drainage and flood protection by the irrigation department. They piled up the sediments on the both sides of the river which further came down into the river through the side slopes in monsoon. Baside this, the adjacent lands of the river are mostly used for agricultural purposes. During the rainy season, the top soil of the bare agricultural land is eroded due to heavy down poor and transported into the river channel along the two side slopes. The disturbed, incompetent river current cannot transport the sediment and maintain the depth of the river as deposition of sediments take place on the bed itself. As a result, the height of the riverbed gradually increases.



Fig.-4 Changing sequence of pool (P) and riffle (R) in 2004 and 2012 
Last century, in the decades of seventy, during the IndoPak war a bridge was constructed on the river Ichamati at Tentulia for rapid militant action to East Pakisthan (now in Bangladesh). This masonry construction regretted the incursion of active tidal water into the first window forming numerous bars into the riverbed. From this time this portion of river became the playing zone of 'push water' of active tidal water. Due to lack of tidal energy, this portion of river lost her capacity to change its bed form. In the second window, the number of bed forms have increased but did not maintain the mean spacing ( 5 to 7 times the channel width: Leopold et. al, 1964). In this section, the river is always trying to adjust with human interference. There are hundreds of brickfields both sides of the river and they indiscriminately collect water and sediments from the river. As a result, the river tries to compensate this loss of sediment by haphazard scouring.

\section{DEVIATION INDEX (DI)}

The ratio between the undulate length of a river course (length of the observed long profile $\left(\mathrm{L}_{\mathrm{OP}}\right)$ and shortest (aerial) distance from its source to mouth $(\mathrm{L})$ is called the Undulate Index. There can be two types of Undulate Indices (UI) of a river long profile: (i) Undulate Index of Observed Long Profile $\left(\mathrm{O}_{\mathrm{PL}}\right)$, and (ii) Undulate Index of Computed Long Profile $\left(\mathrm{C}_{\mathrm{PL}}\right)$. Two types of indices may be suggested on the basis of: (a) $\mathrm{L}_{\mathrm{OP}}$, and (b) Length of the computed long profile or the length of the graded long profile $\left(\mathrm{L}_{\mathrm{CP}}\right)$.
The definitions can be mathematically expressed as :
(a) $\mathrm{O}_{\mathrm{PL}}=\mathrm{L}_{\mathrm{OP}} / \mathrm{L}$ and
(b) $\mathrm{C}_{\mathrm{PL}}=\mathrm{L}_{\mathrm{CP}} / \mathrm{L}$

$\mathrm{L}_{\mathrm{CP}}=$ length of the graded long profile

We can further compute the proximity between these two profiles by Deviation Index. It can help in computing the condition of a river in terms of its grade, or the stage to attain graded condition with the help of numerical value(s) of Deviation Index. As the river always tries to reach the graded level, the Deviation Index always measures the proximity of the grading condition. By this index, we can realize about the proximity of the present observed profile than the graded profile of the river. If the value of the index is greater, the grading condition of the river will be lower. The optimum value of the deviation can be 1 , which signifies a typical graded profile, while a greater value of the Deviation Index (DI) indicates lesser grading condition of the river (Mondal, 2011). However, the Deviation Index is very much specific to the concerned river, and is seldom comparable due to local/ regional geological set up, geomorphic processes, climatic conditions, soil types, vegetation characters, land use patterns etc.

Sen (1993) discussed theoretically the non-grading conditions of some Bengal rivers, with examples of rivers damodar and Khari. Mondal (2011) provided Deviation Index, especially in the context of Ichamati River. The mathematical expression for Deviation Index (DI) is: DI = $\mathrm{O}_{\mathrm{PL}} / \mathrm{C}_{\mathrm{PL}}$

Table- 3. Status of Deviation Index of the River Ichamati (in 2003 and 2010)

\begin{tabular}{|c|c|c|c|c|c|c|c|}
\hline Year & $\begin{array}{c}\text { L OLP } \\
(\mathrm{Km})\end{array}$ & $\begin{array}{l}\text { LCLP } \\
(\mathrm{Km}) \\
\end{array}$ & $\begin{array}{c}\text { Actual } \\
\text { length }(\mathrm{Km})\end{array}$ & $\begin{array}{l}\text { U I of } \\
\left(\mathrm{O}_{\mathrm{PL}}\right)\end{array}$ & $\begin{array}{l}\text { U I of } \\
\left(\mathrm{C}_{\mathrm{PL}}\right)\end{array}$ & (DI) & Remarks \\
\hline 2003 & 128.7 & \multirow[b]{2}{*}{88.5} & \multirow[b]{2}{*}{85.0} & 1.51 & \multirow[b]{2}{*}{1.04} & 1.45 & \multirow{2}{*}{$\begin{array}{l}\text { The profile is more } \\
\text { graded in } 2010 \\
\text { than that of } 2003\end{array}$} \\
\hline 2010 & $\begin{array}{r}95.4 \\
95.4 \\
\end{array}$ & & & 1.12 & & 1.08 & \\
\hline
\end{tabular}

LOLP=Length of observe long profile; $L C L P=$ Length of computed long profile;

\section{CONCLUSION}

The longevity of a distributory channel primarily depends on the input of water that must be provided through the feeder stream and through the tidal water from the mouth. Ichamati river remains disconnected from its feeder streams since long back, and get hardly any water from those sources, except during the rainy season. Consequently, the river fully depends on the incursion of tidal water, but tidal incursion rarely reaches now up to Bangaon. Artificial impounding of water for various economic interests, construction of pillars for bridge in channel bed and typical sinuous tortoise-shell-like gradient are the major causes. The present quantitative study of the river's long profile between bangaon and Basirhat revels that the profile is highly disturbed and uneven due to human interferences that have not only led uncommon to degradation/ aggradatiion along the course, but also prevented enough inflow of tidal water. As a consequence, the river is gradually deteriorating and is likely to decay further the upstream downwards. Diversion of the upstream flow, which is sweet water, for human use is also affecting the river's effort to improve grade. The changing character of pools and riffles on bed form and deviation index of long profile of river Ichamati indicate the gradual decadal condition.

\section{REFERENCES}

1. Anderson, J. K., Wondzell. S.M., Gooseff. M.N., Haggerty. R. 2005: pattern in Stream Longitudinal Profile and Implications For hyporheic exchange Flow AT the H. J. Andrews Experimental Forest, Oregon, U. S. A., Hydrological Processes, 192931-2949 (2005), DOI, 101002/ hy., : 579.

2. Basu, B, and Sil, S. 2003: Arsenic mapping for North 24- Pargana District of West Bengal - using GIS and Remote Sensing technology, Map India Conference 2003, (C) GISdevelopment.net, All rights reserved.

3. Beschta, R. L. and Platts. W. S. 1986 : Morphological Features of small Streams Significance and function, Water Resource Bullitin, 22(3), : 369-379.

4. Bhowmik, N. G., demissie. M.1982 : Bed Material in Pools and Riffles, Journal of the Hydraulics Divission 108 (Hy 10). : 12271231.

5. Box, G. E. M. and Jenkins, G. M. 1976. Time Series Analysis \pm Forecasting and Control, Holden-Day, San Francisco, :553

6. Brierly, G.2008: Goemorphology and River management, Kemanusiaan, 15(2008),:13-26. 
7. Brookes, A. and Shields, Jr. F. D. 1996 : River Restoration; Guiding Principles for Sustainable Projects, J. Willey and ons Ltd. Chichester, U.K.p.

8. Chakraborty, D., Das, D., Rahaman, M.M., Chowdhury, U.K., Biswas, B. 2009: Status of Ground Water arsenic contamination in the etate of W.b., India, A 20 year study report, 53,: 542-551.

9. Clifford, N. J., (1983): Formation of Riffle and Pool Sequences; Field Evidence for an Antogenetic Process, Sedimentary Geology, $85,: 39-51$

10. Clifford, N. J., and K. S. Richards.1992: The Reversa1 Hypothesis and the Maintenance of Riffle-Pool Sequences: A Review and Field Appraisal, in P.A. Carling and G.E . Pett s (eds.) LowIand Floodplain Rivers: Geomorphologicu P erspeclives. Wiley, Chichester,: 43-70.

11. Costigan, K. H., Daniels, M. D., Perkin, J. S., Gido, K.B. 2014: Longitudinal variability in hydraulic geometry and substrate characteristics of a Great Plains sand-bed river, Geomorphology 210 (2014): 51

12. Dorava, J. M., Montogomery, D. R., Palcasak. B. B., Fitzpatrick. F.A.2001:(eds.) Goemorphic Processes and Rivirine Habitat, Washington, American Geophysical Union.

13. Dury, G. H. 1970: A re-survey of part of the Hawkesbury River, New South Wales, after one hundred years', Australian Geographical Studies, 8, 121 \pm 132

14. Foster, G. E.1998: Morphology of Three- Semi Alluvial stream channels in Southern Ontario, Faculty of

15. Graduate Studies, The University of Western Ontario, London, Ontario, Nov. 1998, : 46-54.

16. Frothingham, K. M., and Brown, N. 2002 : OBJECTIVE IDENTIFICATION OF POOLS AND RIFFLES IN A HUMANMODIFIED STREAM SYSTEM Middle States Geographer, 2002, 35:52-60

17. Guneralp, L., Marsotn, R.A. 2012: Process form Linkages in Meander Morphodynamics: bridging Theoretical Modeling and real World Complexity, Process in Physical Geography, Nov. 2012, 36(6):719.

18. Harmar, O. P.2004. Morphological and process dynamics of the Lower Mississippi River. Unpublished PhD thesis, University of Nottingham.

19. Harmar. O. P., Clifford. N.J. 2007: Geomorphological explanation of the Long Profile of the Lower Mississippi River, Geomorphology, 84 (2007), pp.222-240.

20. Higgs. E. 2003: nature by Design: People, Natural Process and ecoclogical Restoration, MA: MIT Press.

21. Jackson. W.L. and Beschta. R.L. 1984: Influences of Increased sand delivery on the Morphology of Sand and Gravel Channel, Water Resources Bulletin, 20(4), :527-533.

22. Keller. E.A., and Melhorn. W.N. 1978 : Rhythmic Spacing and Origin Of Pools and Riffles, Geological Society of American Bulletin, 89: pp. 723-730

23. Knighton, A.D. 1998: Fluvial Forms and Processes. Oxford University Press, Inc., New York, USA.

24. Knighton, D. 1981: Asymmetry of River Channel Cross-sections: Part I Quantitative Indices. Earth Surface Processes and Landforms, 6:581-588.

25. Krueger,A.M., Frothingham, K.M. 2007: Application and Comparison of Geomorphological and Hydrological Pool and Riffle Quantification Methods, The Geographical Bulletin , 2007 by Gamma Theta Upsilon, 48: 85-95.

26. Langbein, W. B., and Leopold, L. B. 1964. Quasi-equilibrium states in channel morphology. Amer. Jour. Sci. 262: 782-94.

27. Lehotský, M. and Grešková. A. 2007. Fluvial geomorphological approach to river assessment - methodology and procedure. Geografický časopis, 59, , 2, 22 tabs. 44 refs.

28. Leopold, L. B. and Langbein, W. B. 1962. The concept of entropy in landscape evolution. U.S. Geol. Surv. Prof. Paper 500-A.

29. Leopold, L.B., Maddock, T. 1953. The hydraulic geometry of stream channels and some physiographic implications. U. S. Geol. Surv. Prof. Pap. 252 (57 pp.).

30. Lisle. T.E. 1982: Effects of Aggradation and Degradation on RifflePool Morphology in Natural gravel Channels, North- Western California, Water Research, 18(6): 1643-1651.

31. Lord. M.L., Germanoski. D., and Allmendinge., N.E. 2009. Fluvial geomorphology: Monitoring stream systems in response to a changing environment, in Young, R., and Norby, L., Geological Monitoring: Boulder, Colorado, Geological Society of America, p.
69-103, doi: 10.1130/2009.monitoring(04). For permission to copy, contact editing@geosociety.org. (C2009 The Geological Society of America. All rights reserved. :76.

32. Madej. M.A. 1999 : temporal and Spatial variability in Thalweg Profiles of a gravel- Bed River, earth Surface Processes and Landforms, 24, : 1153-1169.

33. Mondal, M., Satpati, L. N. 2013: Evaluation of the Character of Long Profile vis-à-vis Discharge Patterns of the River Ichamati in a Selected Stretch of North 24 Parganas District, India, Indian Journal of Power and River Valley Development, 63, 11-12, 183-188.

34. O'Neill, M. P. and Abrahams, A. D. 1984: Objective Identification of Pools and Riffles. Water Resources Research, 20(7): 921-926.

35. Petts, G. E. and Amoros. G. 1996: Fluvial Hydrosystems, Chapman and Hall, London, U.K. : 322. Richards, K. S. 1976a: Channel width and the rime-pool sequence. Geologrcal Society of America Bulletirz, 87: 883 -890.

36. Richards, K. S. 1982. Rivers, Form and Process in Alluvial Channels. Methuen, London.

37. Ritter,F.Dale., Kuchel, R., Miller, R.J. 1985: Process Geomorphology, $3^{\text {rd }}$ edt.Wm. C. Brown Pub.: 150-171, 193-263.

38. Rudra, K.(2014) : Changing river courses in the western part of the Ganga-Brahmaputra delta, Geomorphology 227 (2014) :87-100

39. Sarkar, A. 2004. River Bank Erosion: Geomorphology and Environment, acb publications, kol. : 87, 97,95.

40. Schumm, S.A., Lichty, R.W.1965: Time, space and causality in geomorphology. American Journal of Science 263:110-119.

41. Sengupta, S. 1966: Geological and geophysical studies in western part of Bengal basin, India, Bulletin, American Association of Petroleum Geologists, 50(5):1001-1017.

42. Sikdar, P.K., Sahu, P. 2009: Undrstanding wetland sub-surface hydrology using geologc and isotopic signature, Hydrology Earth System, Sci.,13:1313-1329

43. Sinha, S.K., Parker, G. 1996: Causes of concavity in longitudinal profiles of rivers. Water Resour. Res. 32 :1417-1428.

44. Smith, M. M. Hira, Hora, T , Chakraborty, P, Chakraborty D. K., Savarimuthu, Smith, A. H. 2003. A Dugwell Program to Provide Arsenic-Safe Water in West Bengal, India: Preliminary Results, JOURNAL OF ENVIRONMENTAL SCIENCE AND HEALTH Part A-Toxic/Hazardous Substances \& Environmental Engineering Vol. A38, No. $1: 293$

45. Wolman, M. G.1955: The Natural channel of Brandywine Creek, Pennsylvania, U. S. Geological Survey Professional Paper : 271.

46. Yang, C. T. 1971: Formation of Rimes and Pools. Wuter Resources Research, 7(6): 1567- 1574

47. Yilmaz, L. 2006: Maximum Entropy Theory by Using the Meandering Morphological Investigation, RMZ - Materials and Geo environment, Vol. 53, No. 3, : 323-338. 